\title{
$5 \alpha$-Reductase Inhibitors for Treatment of Benign Prostatic Hyperplasia: A Systematic Review and Meta-Analysis
}

\author{
Jennifer E J Jun, Angus Kinkade, Anthony C H Tung, and Aaron M Tejani
}

\begin{abstract}
Background: Finasteride and dutasteride are competitive inhibitors of $5 \alpha$-reductase enzymes and are commonly used to treat symptomatic benign prostatic hyperplasia (BPH).

Objective: To compare the efficacy and safety of finasteride and dutasteride in terms of clinically important outcomes.

Data Sources: A literature search was performed using the search terms "prostatic hyperplasia", "prostatic hypertrophy", "dutasteride", "finasteride", "quality of life", "adverse drug reaction", and "mortality". The Embase, PubMed, Cochrane Central Register of Controlled Trials, International Pharmaceutical Abstracts, Cumulative Index to Nursing and Allied Health Literature, and Latin American and Caribbean Health Sciences Literature databases were searched from inception to December 2015.
\end{abstract}

Study Selection and Data Extraction: Randomized controlled trials, quasi-randomized trials, and systematic reviews comparing finasteride with dutasteride, either as monotherapy or in combination with $\alpha$-blockers, for treatment of men with BPH were included. The outcomes of interest included need for prostate-related surgery, episodes of acute urinary retention, withdrawals due to adverse events, number of patients experiencing serious adverse events, mortality, and sexual dysfunction.

Data Synthesis: Four studies involving a total of 1879 patients were included in the analysis. There were no significant differences in any of the clinically important outcomes examined: for prostate-related surgery, odds ratio (OR) 2.01 (95\% confidence interval [CI] 0.18-22.24); for episodes of acute urinary retention, OR 1.47 (95\% CI 0.68-3.19); for number of withdrawals due to adverse events, OR 1.10 (95\% CI 0.68-1.75); for total number of patients experiencing adverse events, OR 0.94 (95\% CI $0.78-1.14$ ); for number of patients experiencing serious adverse events, OR 1.31 (95\% CI 0.87-1.97); and for sexual dysfunction, OR 0.83 (95\% CI 0.64-1.08).

Conclusion: There is insufficient evidence to suggest that either finasteride or dutasteride offers an advantage in efficacy or safety over the other, in terms of clinically important outcomes.

Keywords: dutasteride, finasteride, benign prostatic hyperplasia, benign prostatic hypertrophy, $5 \alpha$-reductase inhibitors

Can J Hosp Pharm. 2017;70(2):113-9

\section{RÉSUMÉ}

Contexte : Le finastéride et le dutastéride sont des inhibiteurs compétitifs de l'enzyme 5 alpha-réductase. Ils sont fréquemment employés comme traitement symptomatique de l'hyperplasie bénigne de la prostate (HBP).

Objectif : Comparer l'efficacité et l'innocuité du finastéride et du dutastéride en ce qui concerne les résultats thérapeutiques cliniquement importants.

Sources des données : Une recherche documentaire a été effectuée à l'aide des termes « hyperplasie de la prostate ", " hypertrophie de la prostate ", " dutastéride ", "finastéride ", " qualité de vie ", " réaction indésirable aux médicaments » et " mortalité ». Les bases de données Embase, PubMed, International Pharmaceutical Abstracts, Cumulative Index to Nursing and Allied Health Literature et Latin American and Caribbean Health Sciences Literature ainsi que le Registre central Cochrane des essais comparatifs ont été interrogées pour la période allant de leur création à décembre 2015.

Sélection des études et extraction des données : Les essais comparatifs à répartition aléatoire, les essais quasi-aléatoires et les analyses systématiques qui comparent le finastéride et le dutastéride, en monothérapie ou en association avec des $\alpha$-bloquants, pour le traitement de la HBP chez l'homme, ont été retenus. Parmi les résultats d'intérêt, on comptait : la nécessité de recourir à une chirurgie de la prostate, les épisodes de rétention urinaire aiguë, les retraits de l'étude pour cause d'événements indésirables, le nombre total de patients ayant subi des événements indésirables graves, la mortalité et le dysfonctionnement sexuel.

Synthèse des données : Quatre études comptant au total 1879 patients ont été retenues pour l'analyse. Aucune différence significative n'a été relevée en ce qui touche les résultats thérapeutiques cliniquement importants : la nécessité de recourir à une chirurgie de la prostate (risque relatif approché [RRA] de 2,01, intervalle de confiance [IC] à $95 \%$ de 0,18 à 22,24), les épisodes de rétention urinaire aiguë (RRA de 1,47, IC à $95 \%$ de 0,68 à 3,19), le nombre de retraits de l'étude pour cause d'événements indésirables (RRA de 1,10, IC à $95 \%$ de 0,68 à 1,75), le nombre total de patients ayant subi des événements indésirables (RRA de 0,94 , IC à $95 \%$ de 0,78 à 1,14); le nombre de patients ayant subi des événements indésirables graves (RRA de 1,31, IC à $95 \%$ de 0,87 à 1,97) et le dysfonctionnement sexuel (RRA de 0,83 , IC à $95 \%$ de 0,64 à 1,08).

Conclusion : Il n'y a pas suffisamment de données probantes pour croire que le finastéride ou le dutastéride offrent, l'un par rapport à l'autre, un 
avantage quant à l'efficacité ou à l'innocuité, en ce qui concerne les résultats thérapeutiques cliniquement importants.

Mots clés : dutastéride, finastéride, hyperplasie bénigne de la prostate, hypertrophie bénigne de la prostate, inhibiteurs de l'enzyme 5 alpharéductase

\section{INTRODUCTION}

5 $\alpha$-Reductases (5ARs) are the enzymes responsible for converting testosterone to dihydrotestosterone, which is important for the progression of benign prostatic hyperplasia $(\mathrm{BPH}) . \mathrm{BPH}$ is a common and progressive condition that can impair quality of life. It affects men in an age-dependent manner, with more than $50 \%$ of men over the age of 50 years and close to $90 \%$ of those over 80 being affected. ${ }^{1}$ It is characterized by various lower urinary tract symptoms, including decreased urinary stream, incomplete voiding, urinary frequency, and hesitancy. $^{2}$

By blocking these enzymes, 5AR inhibitors decrease the serum concentration of dihydrotestosterone, inhibiting prostatic growth $^{3}$ and decreasing disease progression. ${ }^{2}$ Two 5AR inhibitors are available: finasteride and dutasteride. Finasteride is a selective inhibitor of the type 2 isoenzyme, whereas dutasteride inhibits both type 1 and type $2 .{ }^{4}$ This difference in mechanism results in a significantly greater and more consistent reduction in dihydrotestosterone with dutasteride than with finasteride ${ }^{4,5}$; however, it is unclear whether this leads to a clinically significant difference.

There have been 3 systematic reviews on the use of dutasteride versus finasteride for the treatment of $\mathrm{BPH},{ }^{6-8}$ but these reviews had several methodologic issues that may affect the reliability of their findings. Bias may have been introduced through inclusion of retrospective cohort studies ${ }^{6}$ and inadequate blinding related to subjective symptoms. ${ }^{8}$ One review included the results of only one trial. ${ }^{7}$ All previous systematic reviews limited their searches to English-language publications.

To address these methodologic limitations, an updated systematic review and meta-analysis of randomized controlled trials (RCTs) was performed, to compare the efficacy and safety of finasteride and dutasteride in adult males with BPH, using a different methodologic approach.

\section{METHODS}

\section{Research Question and Outcomes}

This study was undertaken to answer the following question: In patients with $\mathrm{BPH}$, is either of the two 5AR inhibitors safer or more efficacious than the other, in terms of symptoms, adverse events, and quality of life?
More specifically, we conducted this study to determine whether dutasteride offers an advantage over finasteride in terms of the following clinically relevant outcomes:

- all-cause mortality

- quality of life

- need for prostate-related surgery

- acute urinary retention

- improvement in symptoms

- withdrawal due to adverse events

- number of patients experiencing adverse events

- number of patients experiencing serious adverse events

- sexual dysfunction

\section{Eligibility Criteria}

Studies were included if they were prospective RCTs, quasi-randomized controlled trials, or systematic reviews that compared finasteride and dutasteride head-to-head, either as monotherapy or in combination with $\alpha$-blockers; if they reported at least one of the prespecified clinically relevant outcomes; and if the use of finasteride or dutasteride was not for alopecia or the prevention or treatment of prostatic cancer. The target population was adult males with BPH; no followup or language restrictions were specified.

\section{Study Identification and Selection}

Articles were identified from Embase, PubMed, the Cochrane Central Register of Controlled Trials, International Pharmaceutical Abstracts, Cumulative Index to Nursing and Allied Health Literature, and Latin American and Caribbean Health Sciences Literature databases, based on searching from inception to December 2015. A combination of the following search terms was used: "prostatic hyperplasia", "prostatic hypertrophy", "dutasteride", "finasteride", "quality of life", "adverse drug reaction", and "mortality". After removal of duplicates and screening of titles and abstracts, the full texts of the chosen articles were obtained. All articles were screened and read independently by 2 of the authors (J.E.J.J., A.K.). The reference lists of included articles were also reviewed for any additional studies. For articles that were missing information needed for the current analysis, study authors were contacted for clarification. 


\section{Data Extraction}

Two of the authors (J.E.J.J., A.K.) independently collected data from the included studies on the basis of prespecified outcomes. Outcome values, including change in International Prostate Symptom Score (IPSS), need for surgery, episodes of acute urinary retention, withdrawal due to adverse events, sexual dysfunction, number of patients experiencing serious adverse events, and total adverse events, were collected, if reported. These outcomes were considered to be clinically meaningful, given their quantifiable impact on patient care in acute care settings. Ethics approval was not required for this study.

\section{Quality Assessment}

The Cochrane tool for assessing risk of bias ${ }^{9}$ was used to evaluate the included studies. Two of the authors (J.E.J.J., A.K.) independently rated the risk of bias, and disagreements were resolved through consensus. We felt that the risk-of-bias assessment was more appropriate than a scoring system, as it allows for transparency in how bias was assessed for each study.

\section{Data Analysis}

For continuous outcomes, the mean difference from baseline to end of follow-up, with standard deviation (SD), was used as the summary statistic. For dichotomous outcomes, the odds ratio (OR), with $95 \%$ confidence interval (CI), was used. When the absolute value for a mean difference was not provided, it was calculated from the percent change from the baseline. When the SD of the change from baseline to the final measurement was not given, it was calculated using methods described in the Cochrane Handbook for Systematic Reviews of Interventions. ${ }^{9}$

To assess heterogeneity among studies, the $I^{2}$ statistic was used. ${ }^{9}$ A funnel plot was planned to assess for publication bias if 10 or more trials were identified. All data were analyzed using Review Manager 5.3 (Cochrane Collaboration, Copenhagen, Denmark).

\section{RESULTS}

Initially, 5 studies ${ }^{10-14}$ were identified (Figure 1). Of these, 1 trial did not have useable data ${ }^{10}$ because the absolute number of participants was not provided; we tried to contact the author, but did not receive a response. With the remaining 4 studies, ${ }^{11-14}$ a total of 1879 patients were included in the final analysis. Of the 4 included studies, 1 was blinded ${ }^{14}$ and 3 were openlabel. ${ }^{11-13}$ The method of randomization was not specified in any of the studies. The process of allocation concealment was also not discussed. Study and patient characteristics can be found in Table 1, and the results of the risk-of-bias assessment can be found in Figure 2. Two of the 4 studies used finasteride and dutasteride as monotherapies, ${ }^{12,14}$ whereas concurrent $\alpha$-blockers were used in the others. ${ }^{11,13}$

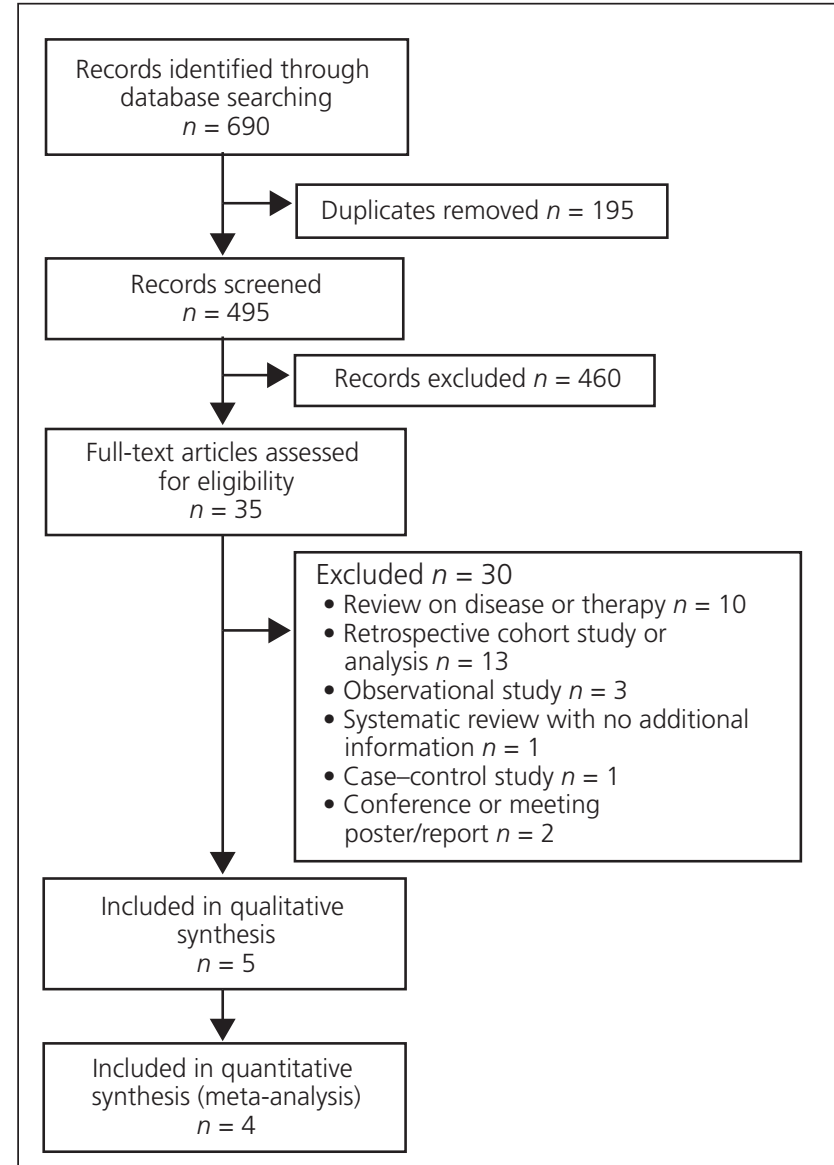

Figure 1. Flow diagram of study selection.

None of the studies reported mortality data, although we think it likely that all trialists had those data available. For this reason, all studies were rated as having high risk of bias in the "selective reporting" category. Change in quality-of-life results were too heterogeneous to be analyzed together, and the findings are therefore summarized narratively. Three of the studies assessed quality of life using the IPSS score. ${ }^{11-13}$ One of these, the trial by Mohanty and others, ${ }^{11}$ showed a statistically significant improvement from baseline with dutasteride relative to the change from baseline with finasteride (10.4-point reduction versus 6.3 -point reduction, respectively; $p<0.001)$. The IPSS scores were not significantly different in the other 2 studies: Jeong and others ${ }^{13}$ observed mean reductions of 5.8 points in the dutasteride group and 5.88 points in the finasteride group, whereas $\mathrm{Li}$ and Wang ${ }^{12}$ observed reductions of 6.7 in the dutasteride group and 6 points in the finasteride group. We were unable to identify the cause of heterogeneity in qualityof-life results among these 3 studies because insufficient information was available. Overall, it does not appear that improvement in quality of life differed between the 2 agents. In 2 of the 3 trials, blinding of participants and personnel was not performed, ${ }^{11,12}$ and blinding was not mentioned in the third. ${ }^{13}$ 
Table 1. Characteristics of Included Studies

\begin{tabular}{|c|c|c|c|c|c|c|}
\hline Reference & $\begin{array}{c}\text { Study } \\
\text { Duration } \\
\text { (months) }\end{array}$ & $\begin{array}{c}\text { No. of } \\
\text { Participants } \\
\text { (Mean Age) }\end{array}$ & $\begin{array}{c}\text { Main } \\
\text { Inclusion } \\
\text { Criteria }\end{array}$ & Main Exclusion Criteria & Treatment & Control \\
\hline $\begin{array}{l}\text { Jeong et al. } \\
(2009)^{13}\end{array}$ & 12 & $\begin{array}{c}n=77 \\
(62.7 \text { years })\end{array}$ & $\begin{array}{l}\geq 50 \text { years of age, } \\
\text { moderate to } \\
\text { severe BPH, on } \\
\text { stable dose of } \\
\text { uroselective } \\
\alpha \text {-blockers, } \\
\text { prostate gland } \\
\geq 25 \mathrm{~cm}^{3}\end{array}$ & $\begin{array}{l}\text { Chronic UTI, prostate or } \\
\text { testicular surgery, prostate } \\
\text { cancer, abnormal PSA, } \\
\text { high probability of urinary } \\
\text { obstruction likely to require } \\
\text { surgery, acute urinary } \\
\text { retention, chronically large } \\
\text { postvoid residual urine } \\
\text { volume, history of 5AR } \\
\text { inhibitor }\end{array}$ & $\begin{array}{l}\text { Dutasteride } \\
0.5 \mathrm{mg}+ \\
\text { alfuzosin } \\
10 \mathrm{mg} \text { (or } \\
\text { tamsulosin } \\
0.2 \mathrm{mg} \text { ) daily }\end{array}$ & $\begin{array}{l}\text { Finasteride } 5 \mathrm{mg} \\
+ \text { alfuzosin } 10 \mathrm{mg} \\
\text { (or tamsulosin } \\
0.2 \mathrm{mg} \text { ) daily }\end{array}$ \\
\hline $\begin{array}{l}\text { Li and Wang } \\
(2013)^{12}\end{array}$ & 6 & $\begin{array}{c}n=72 \\
\text { (mean age } \\
\text { not } \\
\text { reported) }\end{array}$ & $\begin{array}{l}\text { BPH, IPSS }>13 \text {, } \\
Q_{\max }<15 \mathrm{~mL} / \mathrm{s}, \\
\mathrm{PSA}<4 \mu \mathrm{g} / \mathrm{L} \text {, } \\
\text { urine volume } \\
<150 \mathrm{~mL} \text { per } \\
\text { urination }\end{array}$ & $\begin{array}{l}\text { Prostate cancer; urethral } \\
\text { narrowing; bladder } \\
\text { stone; urinary infections; } \\
\text { neurogenic bladder; } \\
\text { lower urinary track } \\
\text { blockage or restriction; } \\
\text { surgical interventions; } \\
\text { BPH medications within } \\
4 \text { weeks before start of } \\
\text { study; heart, lung, liver, } \\
\text { or kidney insufficiency }\end{array}$ & $\begin{array}{l}\text { Dutasteride } \\
0.5 \mathrm{mg} \text { daily }\end{array}$ & $\begin{array}{l}\text { Finasteride } \\
5 \text { mg daily }\end{array}$ \\
\hline $\begin{array}{l}\text { Mohanty et al. } \\
(2006)^{11}\end{array}$ & 6 & $\begin{array}{c}n=100 \\
\text { (mean age } \\
\text { not reported) }\end{array}$ & $\begin{array}{l}40-80 \text { years of } \\
\text { age, BPH, no } \\
\text { indication for } \\
\text { surgery }\end{array}$ & $\begin{array}{l}\text { Prostate cancer suspected } \\
\text { or diagnosed }\end{array}$ & $\begin{array}{l}\text { Dutasteride } \\
0.5 \mathrm{mg}+ \\
\text { tamsulosin } \\
0.4 \mathrm{mg} \text { daily at } \\
\text { night }\end{array}$ & $\begin{array}{l}\text { Finasteride } 5 \mathrm{mg} \\
+ \text { tamsulosin } \\
0.4 \mathrm{mg} \text { daily } \\
\text { at night }\end{array}$ \\
\hline $\begin{array}{l}\text { Nickel et al. } \\
(2011)^{14}\end{array}$ & 12 & $\begin{array}{c}n=1630 \\
(66.8 \text { years })\end{array}$ & $\begin{array}{l}\geq 50 \text { years of age, } \\
\text { BPH, AUA-SI } \\
\geq 12 \text { points, } \\
\text { prostate volume } \\
\geq 30 \mathrm{~cm}^{3}, \\
Q_{\max }<15 \mathrm{~mL} / \mathrm{s}, \\
\text { minimum voided } \\
\text { volume } \geq 125 \mathrm{~mL}\end{array}$ & $\begin{array}{l}\text { Postvoid residual volume } \\
>250 \mathrm{~mL} \text {, history or } \\
\text { evidence of prostate } \\
\text { cancer, previous prostatic } \\
\text { surgery or invasive BPH } \\
\text { treatment procedure, } \\
\text { history of acute urinary } \\
\text { retention in the past } \\
3 \text { months, PSA }<1.5 \mathrm{ng} / \mathrm{mL} \\
\text { or }>10 \mathrm{ng} / \mathrm{mL} \text {, use of } 5 \mathrm{AR} \\
\text { inhibitors, use of } \alpha \text {-blockers } \\
\text { within } 2 \text { weeks of screening } \\
\text { visit and throughout study }\end{array}$ & $\begin{array}{l}\text { Dutasteride } \\
0.5 \mathrm{mg} \text { daily }\end{array}$ & $\begin{array}{l}\text { Finasteride } \\
5 \text { mg daily }\end{array}$ \\
\hline
\end{tabular}

5AR $=5 \alpha$-reductase, AUA-SI = American Urological Association - Symptom Index, BPH = benign prostatic hyperplasia,

IPSS = International Prostate Symptom Score, PSA = prostate-specific antigen, $Q_{\max }=$ maximum urinary flow rate,

$\mathrm{UTI}=$ urinary tract infection.

Symptom improvement was reported by only one trial. ${ }^{14}$ In that trial, there was no difference in symptoms, as measured by the Symptom Index of the American Urological Association, between dutasteride and finasteride (reductions of 5.8 and 5.5 points, respectively). Although the trial was blinded, to limit biases, it was not adequately powered to detect a difference.

Two studies reported on the need for prostate-related surgery ${ }^{13,14}$; however, one study had no events, ${ }^{13}$ and the other did not report a statistically significant difference and was not adequately powered to detect a difference ${ }^{14}$ (Figure 3).

The number of episodes of acute urinary retention was reported in 3 studies, ${ }^{11,13,14} 2$ of which had no events. ${ }^{11,13}$ In the single study with events, no statistically significant difference was found, although it was not adequately powered to detect a difference (OR 1.47, 95\% CI 0.68-3.19)..$^{14}$
Of the 3 studies that reported on the number of withdrawals due to adverse events, only 1 study reported any events. ${ }^{14}$ In that trial, although there were numerically more withdrawals secondary to adverse events in the dutasteride group, the difference between groups was not statistically significant (OR 1.10, 95\% CI 0.68-1.75). Similarly, there were no statistically significant differences between dutasteride and finasteride in terms of either number of patients experiencing serious adverse events (OR 1.31, 95\% CI 0.87-1.97) or total number of patients experiencing adverse events (OR 0.94, 95\% CI 0.78-1.14).

Finally, the analysis did not demonstrate a difference between dutasteride and finasteride with regard to sexual dysfunction (OR 0.83, 95\% CI 0.64-1.08). 


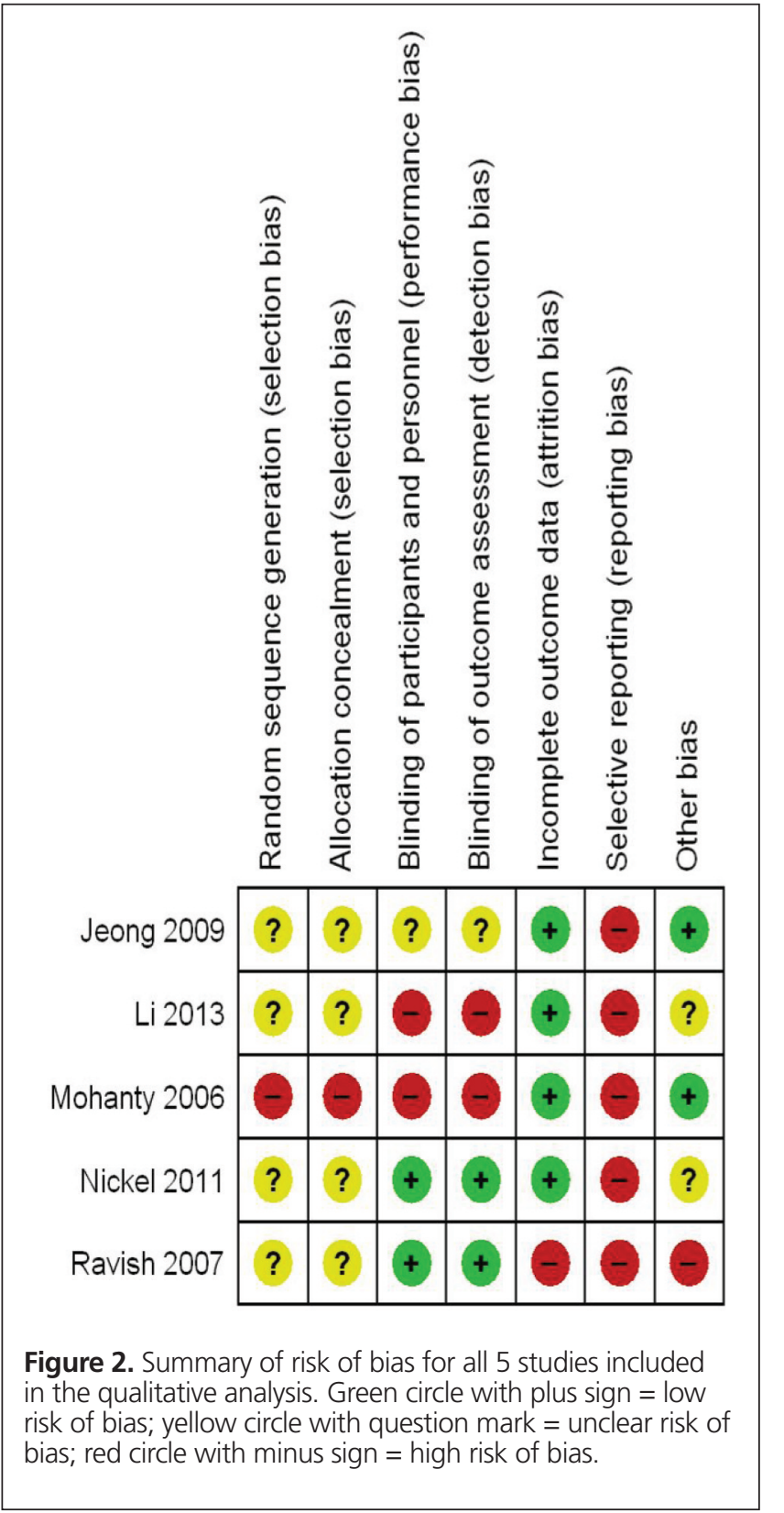

\section{Sensitivity Analyses}

Removing trials that had at least one component rated as having high risk of bias did not change the results of the analyses in any meaningful way. The trials removed for this sensitivity analysis had few patients and, in many analyses, no events.

A sensitivity analysis was also conducted to assess the impact of patients who were lost to follow-up. Numbers for the various outcomes were adjusted to reflect worst-case scenarios, whereby all patients lost to follow-up in either arm experienced the outcome of interest. In these analyses, there was no change in the results.

\section{DISCUSSION}

We did not find any evidence that either dutasteride or finasteride offers a clinically relevant advantage over the other agent. No statistically significant differences were detected in the outcomes of interest examined from the studies included in this analysis.

To date, 3 systematic reviews have compared dutasteride and finasteride. Gacci and others ${ }^{7}$ conducted a meta-analysis on treatments for $\mathrm{BPH}$ and reported findings from the only trial available at the time, which was also included in the current review. ${ }^{14}$ Conte and others ${ }^{6}$ found no head-to-head RCTs but concluded, from 3 retrospective cohort studies, that dutasteride may be more effective in terms of acute urinary retention and need for surgery. These findings are not consistent with the current results, which did not demonstrate a statistically significant difference between the 2 agents. The contrast may be because, to reduce bias, our study included head-to-head RCTs and excluded retrospective studies. Observational, retrospective trials are at greater risk of confounding because of unknown baseline differences between groups. ${ }^{15}$ The Cochrane Handbook for Systematic Reviews of Interventions ${ }^{9}$ suggests 3 situations when researchers performing a systematic review of an intervention should consider including nonrandomized studies: when making the case for an RCT to

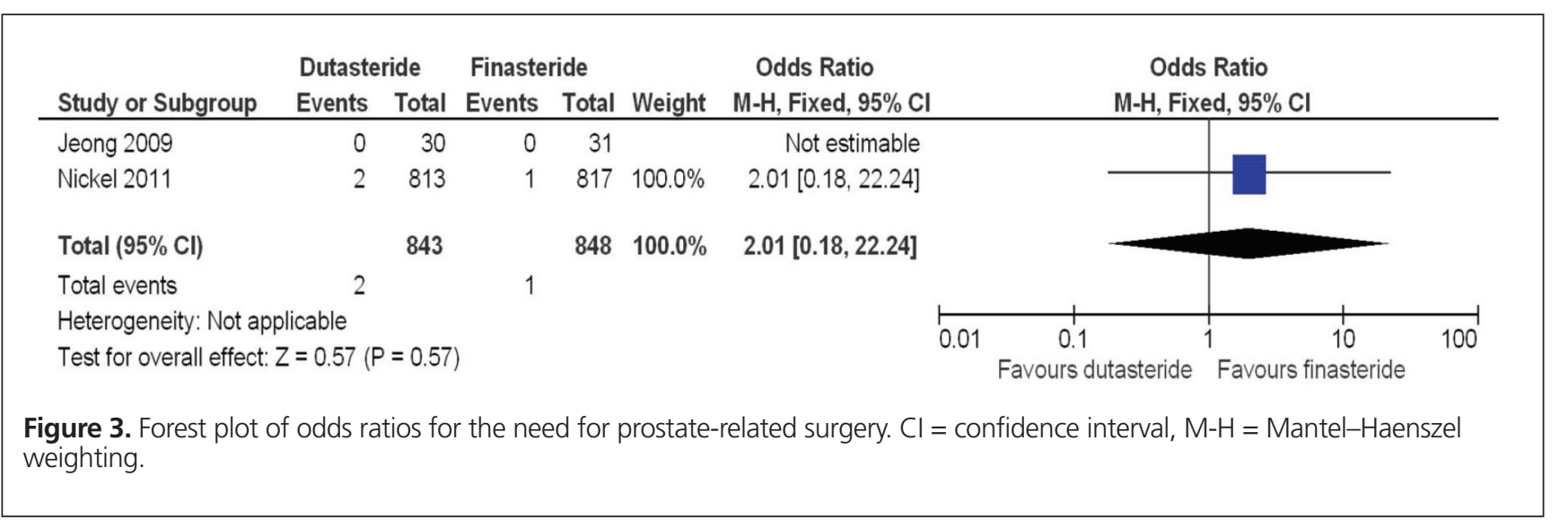


be performed (where none exists), when randomization to the experimental intervention is not possible, and when long-term or rare events are being measured and these events are unlikely to occur during a relatively short-term RCT. In our opinion, none of these situations apply to the current review.

In the third of the previous systematic reviews, Park and $\mathrm{Choi}^{8}$ reviewed the literature comparing dutasteride with placebo and finasteride. Although they were able to compare dutasteride with finasteride only for the outcomes of any adverse events and any drug-related adverse events, they found no difference between the 2 medications. The literature search for the current review identified an additional 3 trials by expanding the search criteria to include non-English and openlabel trials. However, these additional data did not substantially alter the findings. Park and $\mathrm{Choi}^{8}$ also compared dutasteride with placebo and showed that dutasteride produced a significant reduction in IPSS score relative to placebo. The results of the current review may indicate that their findings may also be generalizable to finasteride, as there does not appear to be a demonstrable difference between the 2 agents.

Change in IPSS was an outcome that could not be subjected to meta-analysis because of heterogeneity. It is also worth mentioning that 3 of the 4 included studies were not blinded. Because IPSS is a subjective measure, with patients evaluating their own symptoms, nonblinded studies using IPSS carry a high risk of bias: if patients know that they are taking an experimental treatment, they may feel more positive about their symptom improvement. A 2012 study concluded that effects reported by patients in terms of subjective outcomes were considerably more optimistic in nonblinded studies than in blinded studies. ${ }^{16}$ One nonblinded trial ${ }^{11}$ showed significantly better improvement in quality of life with dutasteride than with finasteride; however, this trial was the primary reason for heterogeneity in this outcome, and excluding it during the sensitivity analysis eliminated all heterogeneity. On the basis of the available clinical trial evidence, dutasteride and finasteride should produce similar improvements in the quality of life of patients with BPH.

The lack of statistical significance in the results reported here could be due to an inadequate number of participants, which may represent a limitation of the present review. Of the 1879 patients included in this meta-analysis, 1630 were from the trial by Nickel and others. ${ }^{14}$ That trial was powered to detect a change in prostate volume ${ }^{14}$ but may have been insufficiently powered to detect differences in other outcomes. Because the primary trial in the majority of analyses was not powered to detect differences between the agents in clinically important outcomes, it would be premature to declare that no such differences exist. The performance of additional studies, even if inadequately powered on their own, could be used to reduce the uncertainty of this finding in future meta-analyses. Also, to determine whether true clinical differences exist between the 2 agents, blinded studies are required to assess the impact of subjective outcomes, such as change in quality life, to be incorporated into future meta-analyses.

This review included only RCTs with head-to-head comparisons of dutasteride and finasteride that reported clinically important health outcomes. Because our intent was to apply research findings to real patient care in acute care settings, we felt it was important to focus on clinical outcomes that matter to patients. Some commonly reported measures, such as prostate volume and urinary flow rate, are numbers that may not be meaningful to patients and their quality of life, and they have not been correlated with patients' quality of life. ${ }^{17,18}$ We therefore deemed them irrelevant for the purposes of this review. However, some clinicians may disagree with our choice of outcomes, which may limit the generalizability of this review to their practices.

The search was not extended to the grey literature, which may be a limitation of the present review. It is possible that additional results could have been identified had regulatory documents and conference proceedings been consulted.

Both English and non-English studies were reviewed and included, which was not done in previous systematic reviews. Also, the Cochrane tool for assessing risk of bias was used to evaluate the quality of the studies; this tool allows for more transparency in reporting than other bias-scoring systems. Using the Cochrane risk-of-bias tool also eliminates the inherent weighting of biases that are incorporated in scoring tools.?

\section{CONCLUSION}

There were no statistically significant differences between finasteride and dutasteride in terms of efficacy and safety outcomes reported in the studies included in this systematic review. There does not appear to be any evidence that using one of these agents rather than the other will yield additional benefit, although the included studies did not contain enough data to adequately power these comparisons.

\section{References}

1. Roehrborn C, McConnell J. Etiology, pathophysiology, epidemiology and natural history of benign prostatic hyperplasia. In: Walsh P, Retik A, Vaughan Jr E, Wein AJ, editors. Campbell's urology. 8th ed. Philadelphia (PA): W B Saunders; 2002. pp. 1297-330.

2. Naslund M, Regan TS, Ong C, Hogue SL. 5-Alpha reductase inhibitors in men with an enlarged prostate: an evaluation of outcomes and therapeutic alternatives. Am J Manag Care. 2008;14(5 Suppl 2):S148-53.

3. Carson $\mathrm{C}$, Rittmaster $\mathrm{R}$. The role of dihydrotestosterone in benign prostatic hyperplasia. Urology. 2003;61(4 Suppl 1):2-7.

4. Nickel JC. Comparison of clinical trials with finasteride and dutasteride. Rev Urol. 2004;6 Suppl 9:S31-9.

5. Clark RV, Hermann DJ, Cunningham GR, Wilson TH, Morrill BB, Hobbs S. Marked suppression of dihydrotestosterone in men with benign prostatic hyperplasia by dutasteride, a dual 5alpha-reductase inhibitor. J Clin Endocrinol Metab. 2004;89(5):2179-84. 
6. Conte T, Truzzi JC, Tannus G, Fonseca M. Systematic review comparing the efficacy of the 5-alpha reductase inhibitors (5-ARIs) dutasteride and finasteride in the treatment of benign prostatic hyperplasia (BPH) [abstract PIH5]. Value Health. 2012;15(4):A192. Also available from: www. valueinhealthjournal.com/article/S1098-3015(12)01102-3/abstract

7. Gacci M, Ficarra V, Sebastianelli A, Corona G, Serni S, Shariat SF, et al. Impact of medical treatments for male lower urinary tract symptoms due to benign prostatic hyperplasia on ejaculatory function: a systematic review and meta-analysis. J Sex Med. 2014;11(6):1554-66.

8. Park T, Choi JY. Efficacy and safety of dutasteride for the treatment of symptomatic benign prostatic hyperplasia (BPH): a systematic review and meta-analysis. World J Urol. 2014;32(4):1093-105.

9. Higgins J, Green S, editors. Cochrane handbook for systematic reviews of interventions. Version 5.1.0. The Cochrane Collaboration; [updated 2011 Mar; cited 2016 Nov 28]. Available from: www.handbook.cochrane.org

10. Ravish IR, Nerli RB, Amarkhed SS. Finasteride to evaluate the efficacy of dutasteride in the management of patients with lower urinary tract symptoms and enlarged prostate. Arch Androl. 2007;53(1):17-20.

11. Mohanty NK, Singh UP, Sharma NK, Arora RP, Amitabh V. A comparative study of fixed dose of tamsulosin with finasteride vs tamsulosin with dutasteride in the management of benign prostatic hyperplasia. Indian J Urol. 2006;22(2):130-4.

12. Li Y, Wang J. Clinical efficacy and safety analysis of dutasteride in treatment of benign prostatic hyperplasia. Chinese J Androl. 2013;27(7):49-55.

13. Jeong YB, Kwon KS, Kim SD, Kim HJ. Effect of discontinuation of 5 alphareductase inhibitors on prostate volume and symptoms in men with $\mathrm{BPH}$ : a prospective study. Urology. 2009;73(4):802-6.

14. Nickel JC, Gilling P, Tammela TL, Morrill B, Wilson TH, Rittmaster RS. Comparison of dutasteride and finasteride for treating benign prostatic hyperplasia: the Enlarged Prostate International Comparator Study (EPICS). BJU Int. 2011;108(3):388-94.

15. Barton $S$. Which clinical studies provide the best evidence? The best RCT still trumps the best observational study. BMJ. 2000;321(7256):255-6.

16. Hróbjartsson A, Thomsen ASS, Emanuelsson F, Tendal B, Hilden J, Boutron I, et al. Observer bias in randomised clinical trials with binary outcomes: systematic review of trials with both blinded and non-blinded outcome assessors. BMJ. 2012;344:e1119.
17. Eckhardt MD, Van Enrooij GEP., Boon TA. Symptoms and quality of life versus age, prostate volume, and urodynamic parameters in 565 strictly selected men with lower urinary tract symptoms suggestive of benign prostatic hyperplasia. Urology. 2001;57(4):695-700.

18. Agrawal CS, Chalise PR, Bhandari BB. Correlation of prostate volume with international prostate symptom score and quality of life in men with benign prostatic hyperplasia. Nepal Med Coll J. 2008;10(2):104-7.

Jennifer $\mathbf{E} \mathbf{J}$ Jun, BSc(Pharm), is with the Providence Crosstown Clinic, Vancouver, British Columbia.

Angus Kinkade, BSC(Pharm), ACPR, PharmD, MSc, is with Lower Mainland Pharmacy Services, Vancouver, British Columbia.

Anthony C H Tung, BSC(Pharm), ACPR, MBA, is with Lower Mainland Pharmacy Services, Surrey, British Columbia.

Aaron M Tejani, BSc(Pharm), PharmD, is with Lower Mainland Pharmacy Services, Vancouver, British Columbia.

Competing interests: For activities not directly related to the topic of this article, Aaron Tejani has received a grant from the College of Pharmacists of British Columbia and payment for lectures on a variety of topics from the University of British Columbia, Vancouver Island Health Authority Pharmacy Services, and various professional societies and organizations; he also serves on the UBC Therapeutics Initiative. No other competing interests were declared.

\section{Address correspondence to:}

Dr Angus Kinkade

Lower Mainland Pharmacy Services

Vancouver General Hospital

Heather Pavilion, Level D

2733 Heather Street

Vancouver BC V5Z $1 \mathrm{M} 9$

e-mail: angus.kinkade@fraserhealth.ca

Funding: None received.

\section{$\operatorname{cshp}$ \\ Scph}

\section{CSHP Members Save on} ASHP and Pharmaceutical Press Publications!

CSHP members are invited to place their orders for all ASHP and Pharmaceutical Press products and publications through our website: www.lb.ca/CSHP.

\section{CSHP members also save on cross border shipping charges through Login Canada!}

CSHP members can obtain the password needed to place an order for ASHP, Pharmaceutical Press, and other products and publications by going to the Products and Publications tab on the CSHP homepage. From there, please scroll down to Products and Other Publications and select ASHP/ Pharmaceutical Press. Members will be asked to login before being allowed to proceed to CSHP's virtual bookstore.

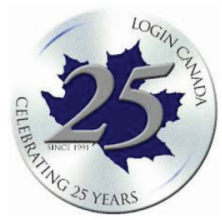

